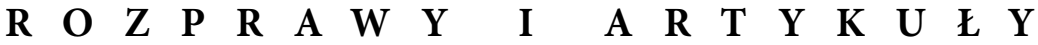

Prawo Kanoniczne

59 (2016) nr 3

KS. JÓZEF WROCEŃSKI SCJ

Wydział Prawa Kanonicznego

Uniwersytet Kardynała Stefana Wyszyńskiego w Warszawie

\section{GODNOŚĆ OSOBY LUDZKIEJ PODSTAWĄ PRAWA DO WOLNOŚCI RELIGIJNEJ}

Treść: Wstęp. - 1. Koncepcja podstawowych praw człowieka. - 2. Pojęcie godności ludzkiej. - 3. Godność ludzka w nauczaniu Kościoła katolickiego. - 4. Godność ludzka w dokumentach prawa świeckiego. 4.1. W dokumentach prawa międzynarodowego. - 4.2. W dokumentach prawa europejskiego. - 4.3. W Konkordacie polskim. - 4.4. W Konstytucji Rzeczypospolitej Polskiej. - Zakończenie

\section{Wstęp}

Wszelkie prawa przysługują człowiekowi tylko dlatego, że jest osobą. Mają one uniwersalny charakter i każdemu człowiekowi przysługują w równej mierze. Prawa człowieka przysługują każdemu bez względu na treść prawa stanowionego i postępowanie człowieka. Są one niezbywalne, nie można ich utracić czy też zrzec się na czyjąś korzyść, ponieważ istnieją one niezależnie od władzy. Zadaniem zaś prawa stanowionego przez państwa i organizacje międzynarodowe jest ochrona tych podstawowych praw człowieka, w tym także prawa do wolności sumienia i religii. To prawo zostało potwierdzone przez najważniejsze akty prawa międzynarodowego, a także przez ustawy zasadnicze większości współczesnych państw. Celem tych gwarancji prawnych dotyczących wolności sumienia i religii jest zapewnienie ludziom ochrony w wyznawaniu i propagowaniu poglądów religijnych, filozoficznych i społecznych. Należy też dodać, że gwarancje te obejmują również prawo do wychowania i nauczania dzieci zgodnie $\mathrm{z}$ własnymi przekonaniami. 
Polski ustawodawca w najważniejszym akcie prawnym, czyli w Konstytucji Rzeczypospolitej Polski z 1997 r. wyjaśnia rozumienie treści prawa do wolności religijnej. Zgodnie z postanowieniem art. 53 polskiej ustawy zasadniczej wolność religii obejmuje wolność wyznawania lub przyjmowania religii według własnego wyboru oraz jej uzewnętrzniania indywidualnie lub $\mathrm{z}$ innymi, publicznie lub prywatnie przez uprawianie kultu, modlitwę, uczestniczenie w obrzędach, praktykowanie i nauczanie. Obejmuje ona też posiadanie świątyń i innych miejsc kultu w zależności od potrzeb wierzących oraz prawo osób do korzystania z pomocy religijnej tam, gdzie się znajdują.

Rodzi się jednak pytanie, co jest podstawą praw człowieka, w tym także tak rozumianego prawa do wolności religijnej, w czym prawodawcy upatrują źródło tego prawa i czy to źródło jest jednakowo pojmowane?

\section{Koncepcja podstawowych praw człowieka}

$\mathrm{Na}$ wstępie należy zauważyć, że koncepcja podstawowych praw człowieka nie jest osiągnięciem XX wieku. Jej początek sięga czasów starożytnych, a szczególnie filozofii Greków i Rzymian. Następnie została ona przejęta przez zachodnią myśl chrześcijańską, która opierała się na rzymskiej koncepcji prawa natury. W tej optyce w XII wieku Jan z Salisbury stworzył koncepcję prawa do oporu przeciwko złemu władcy, który łamie prawa boskie. W następnym stuleciu Wiliam Kocham wprowadził pojęcie praw jednostki. Duży wkład w koncepcję praw człowieka miał polski uczony z przełomu XIV i XV wieku, Paweł Włodkowic. Wiele idei głoszonych przez niego znalazło się we współczesnych koncepcjach praw człowieka ${ }^{1}$.

Pierwszymi jednak autorami, którzy w sposób świadomy posługiwali się podmiotowymi prawami człowieka, byli myśliciele z XVII wieku, tacy jak Thomas Hobbes, John Locke, Baruch Spinoza, a zwłaszcza uczeni z XVIII wieku Karol Monteskiusz i Jan Jakub Rousseau, którzy znaczenie terminu „prawo” zaczęli odnosić do osoby w przedmiocie posiadania czegoś lub działania zgodnie

\footnotetext{
${ }^{1}$ Por. J. HoŁdA, Prawa człowieka. Zarys wykładu, Warszawa 2008, s. 15.
} 
ze sprawiedliwością ${ }^{2}$. Koncepcja praw człowieka przez nich wypracowana opierała się na niezależnych od państwa, powszechnych, przyrodzonych, niezbywalnych i nienaruszalnych prawach człowieka. Zostały w niej wyeksponowane trzy podstawowe cechy: 1) indywidualizm, polegający na dobru człowieka, które jest wartością ważniejszą niż dobro państwa, 2) stan natury, który poprzedzał powstanie społeczeństwa i państwa, 3) teoria umowy społecznej, która miała być źródłem i podstawą istnienia społeczeństwa oraz państwa ${ }^{3}$.

Tak rozumiane prawa człowieka zostały zapisane w pierwszych ustawach zasadniczych pod koniec XVIII wieku, a więc w konstytucjach Stanów Zjednoczonych, Francji i Polski oraz we francuskiej Deklaracji Praw Człowieka i Obywatela z 1789 roku ${ }^{4}$. Wprowadzenie tych praw w większości państw świata i na arenie międzynarodowej nastąpiło dopiero w połowie XX wieku. Przyczyniły się do tego tragiczne doświadczenia dwóch wojen światowych. Szczególnie w czasie drugiej wojny światowej pozbawiono godności i zamordowano w bestialski sposób miliony ludzi w imię totalitarnych systemów: nazizmu i komunizmu. To spowodowało nowe spojrzenie na podstawowe prawa człowieka, które polegało na odwołaniu się do godności człowieka. W aktach normatywnych zaczęto podkreślać, że prawa człowieka to całokształt praw oraz wolności, które przysługują każdemu człowiekowi, bez względu na jego rasę, kolor skóry, wyznanie, poglądy, płeć, język, narodowość, pochodzenie społeczne itp. ${ }^{5}$ Źródłem tych praw jest godność ludzka. Istnieją one niezależnie od władzy, czyli od państwa. Co więcej, są one nienaruszalne, czyli nie mogą być przez władzę regulowane. Państwu przypisuje się jedynie rolę instytucji, której zadaniem jest ich ochrona. Samo zaś poszanowanie praw człowieka i godności osoby ludzkiej jest uznawane za podstawę sprawiedliwości i pokoju na świecie ${ }^{6}$.

\footnotetext{
${ }^{2}$ Por. K. Мотүка, Prawa człowieka, Lublin 1999, s. 15.

${ }^{3}$ Por. Tamże, s. 16.

${ }^{4}$ Por. J. HoŁdA, Prawa człowieka..., s. 20-21.

${ }^{5}$ Por. A. Paszko, Prawa człowieka. Wybór, Kraków 2005, s. 7.

${ }^{6}$ Por. Tamże.
} 


\section{Pojęcie godności ludzkiej}

Pojęcie godności wywodzi się z łacińskiego terminu dignitas, który oznaczał godność, poważanie, szacunek ${ }^{7}$. Tym terminem określano godność człowieka, jak i godność osobistą. Godność człowieka z kolei rozumiano jako cechy gatunku, które przysługiwały ludziom. Godność zaś osobistą pojmowano jako właściwość człowieka, której odzwierciedleniem były wyznawane przez niego wartości i przestrzegane zasady moralne ${ }^{8}$. Obecnie termin godność jest definiowany jako poczucie świadomości własnej wartości, szacunek dla samego siebie, honor, duma, a także zaszczytny urząd, tytuł, funkcja, a nawet nazwisko występujące w wyrażeniach grzecznościowych ${ }^{9}$.

Odwołanie się do godności człowieka znajdujemy już w pierwszej Księdze Pisma Świętego, w Księdze Rodzaju, gdzie Autor mówi, że człowiek został stworzony na obraz i podobieństwo Boż $\mathrm{e}^{10}$. Człowiek był uważany za istotę wyjątkową już w starożytnej filozofii greckiej. Podobnie pojmowali osobę ludzką przedstawiciele kolejnych kierunków filozoficznych, takich jak rzymska filozofia stoicka, średniowieczna filozofia prawa naturalnego, renesansowa myśl filozoficzno-teologiczna oraz współczesna racjonalistyczna filozofia prawa naturalnego. Ten ostatni kierunek stał się podstawą deklaracji praw człowieka i obywatela ${ }^{11}$.

Przypuszcza się, że jako pierwszy zdefiniował podstawy pojęcia godności człowieka, na przełomie V i VI wieku, rzymski filozof Boecjusz. Uważał on, że człowiek jest osobą, co oznaczało według niego, że jest on indywidualną substancją natury rozumnej. To określenie dało początek personalistycznemu pojmowaniu człowieka, które później rozwinął św. Tomasz z Akwinu. Uznał on, że bycie podmiotem

\footnotetext{
${ }^{7}$ Por. M. KuryŁowicz, Słownik terminów, zwrotów i sentencji prawniczych łacińskich oraz pochodzenia łacińskiego, Zakamycze 2005, s. 32.

${ }^{8}$ Por. H. Piluś, O godności człowieka jako osoby, Studia Filozoficzne 7-8(1989), s. 166.

${ }^{9}$ Por. Słownik języka polskiego, t. I, Warszawa 1978, s. 673.

${ }^{10} \mathrm{Rdz} 1,26$.

${ }^{11}$ Por. J. Krukowski, Kościót i Państwo. Podstawy relacji prawnych, Lublin 2000, s. 89 .
} 
godności czyni z człowieka osobę. Dzięki godności człowiek może być wolny, realizować siebie samego, jako osobę i swój indywidualny cel życia. Zainteresowanie pojęciem godności człowieka powróciło w epoce renesansu, a następnie umocnione zostało przez współczesny personalizm chrześcijański, zgodnie z którym godność człowieka ma charakter przyrodzony i nadprzyrodzony. Przyrodzony, bowiem wywodzi się z prawa naturalnego, a nadprzyrodzony, bo wiąże się ze stworzeniem człowieka na obraz i podobieństwo Boga ${ }^{12}$.

Współczesna koncepcja praw człowieka opiera się na pojęciu godności ludzkiej sformułowanej przez I. Kanta. Pokrywa się ona częściowo z pojęciem wypracowanym przez Arystotelesa i św. Tomasza z Akwinu. Według Kanta godność ludzka jest wartością nieporównywalną z niczym innym. To wolność osobista, to bycie podmiotem, który samodzielnie wyznacza własne cele. I. Kant w przeciwieństwie do św. Tomasza nie podkreślał znaczenia indywidualizmu jednostki ludzkiej, ale uważał, że doskonałość może być osiągnięta poprzez postępowanie według powszechnych norm, czyli zgodnie ze sformułowanym przez niego imperatywem kategorycznym. Podobnie jak św. Tomasz Kant pojmował godność ludzką jako wrodzony atrybut każdej osoby ludzkiej, którego nie można się pozbyć, utracić ani wymienić na jakieś inne dobro. Godność ludzka przysługuje każdemu, tylko $\mathrm{z}$ tego powodu, że jest człowiekiem ${ }^{13}$.

Godność ludzka nie została zdefiniowana w żadnym akcie prawa stanowionego ${ }^{14}$. Jej dookreślenie pozostawiono nauce prawa ${ }^{15}$. Prawo uznaje pojęcie godności człowieka za pewną wartość kulturową, której podstawą jest poczucie wewnętrznej wartości i odpowiedzialności. Tak pojęta godność wiąże się z istotą człowieczeństwa. Jej źródłem jest ludzka zdolność myślenia, co stawia człowieka wyżej niż inne

\footnotetext{
${ }^{12}$ Por. K. Мотука, Prawa człowieka, s. 26.

${ }^{13}$ Por. Leksykon ochrony praw człowieka. 100 podstawowych pojęć, red. M. Balcerzak, S. Sykuna, Warszawa 2010, s. 145-146.

${ }^{14}$ Por. Wolności i prawa człowieka w Konstytucji Rzeczypospolitej Polskiej, red. M. Chmaj, Warszawa 2008, s. 28.

${ }^{15}$ Por. Leksykon ochrony praw człowieka..., s. 144.
} 
stworzenia, które nie posiadają tej zdolności. Każda osoba posiada świadomość odróżniającą od zwierząt i dzięki niej człowiek podejmuje działania za pomocą rozumnych i wolnych decyzji, nie zaś za pomocą instynktów i chwilowych impulsów ${ }^{16}$. $Z$ tej też racji godność ludzka nie zależy od wieku, stanu posiadania, obywatelstwa czy poziomu umysłowego. Posiadają ją wszyscy ludzie bez względu na to, gdzie się znajdują i co robią. Godność ludzką posiada każdy człowiek od momentu stania się istotą ludzką ${ }^{17}$.

Godność ludzka, mimo że jak wspomniano wyżej, nie została zdefiniowana w żadnym akcie prawnym, to jednak jest uznawana za podstawową kategorię antropologiczną występującą we współczesnych systemach prawnych. Jako termin pojawiła się po drugiej wojnie światowej. Od tego czasu stanowi etyczną podstawę porządku międzynarodowego. Zaczęła być używana w międzynarodowych i konstytucyjnych systemach prawnych jako instrument ochrony praw człowieka. Godność ludzka stanowi bardzo ważną wskazówkę interpretującą stosowanie norm prawnych związanych z prawami i wolnościami obywatelskimi ${ }^{18}$.

\section{Godność ludzka w nauczaniu Kościoła katolickiego}

W kształtowanie się pojęcia godności ludzkiej niepodważalny wkład wniósł Kościół katolicki, który wcześniej niź świeckie systemy filozoficzne zajął się tym zagadnieniem. Jak już wspomniano wyżej, nawiązania do godności człowieka można znaleźć już w Księdze Rodzaju, gdzie jest mowa o tym, że człowiek został stworzony na obraz i podobieństwo Boże. Koncepcja człowieka jako osoby pojawiła się w chrześcijaństwie jako próba wyjaśnienia struktury bytowej Jezusa Chrystusa, który był prawdziwym człowiekiem i prawdziwym

\footnotetext{
${ }^{16}$ Por. J. KRUkowski, Godność człowieka podstawa konstytucyjnego katalogu praw $i$ wolności jednostki, w: Podstawowe prawa jednostki i ich sądowa ochrona, red.

L. Wiśniewski, Warszawa 1997, s. 39.

${ }^{17}$ Por. Wolności i prawa człowieka..., s. 28-29; 37.

${ }^{18}$ Por. Leksykon ochrony praw człowieka..., s. 144.
} 
Bogiem $^{19}$. Pojęciem godności człowieka posługiwali się Ojcowie Kościoła, m.in. św. Ambroży. Jednak pierwszym uczonym, który stworzył podstawy definicji człowieka jako osoby, był wspomniany wyżej, św. Tomasz z Akwinu. Nawiązał on do koncepcji stworzonej przez Arystotelesa, który uważał, że godność człowieka to złoty środek między jego wadami: zarozumialstwa i służalczości. Definicja godności ludzkiej sformułowana przez św. Tomasza składa się z dwóch elementów. Pierwszy zakazuje instrumentalnego traktowania człowieka, bowiem jest on wolny i może realizować samego siebie, jako osobę oraz swój indywidualny cel życia, a drugi zakazuje bycia celem samym dla siebie, ponieważ człowiek istnieje nie tylko dla siebie, ale i dla innych ${ }^{20}$. Św. Tomasz podkreślał, że niemożliwe jest zrozumienie człowieka i jego posłannictwa bez Ewangelii i zbawczej misji Chrystusa. Człowiek powinien dążyć do spełnienia celu ostatecznego, jakim może być tylko Bóg i zbawienie ${ }^{21}$.

Współcześnie godność człowieka jest uzasadniana przez Kościół przy pomocy dwóch rodzajów argumentów, naturalnych i nadprzyrodzonych. Argumenty naturalne bazują na fakcie, że godność ludzka wynika z posiadania przez człowieka rozumu i wolności oraz używania sumienia ${ }^{22}$. Argumenty nadprzyrodzone przemawiające za godnością człowieka opierają się na stworzeniu człowieka przez Boga. Jest to podstawa godności ludzkiej. Istnienie człowieka jest ukierunkowane na Boga, który powinien być ostatecznym celem ziemskich dążeń człowieka.

Należy zauważyć, że godność człowieka była tematem często podejmowanym przez papieża św. Jana Pawła II. W stworzonej przez siebie koncepcji godności osoby ludzkiej odwoływał się on do trzech

\footnotetext{
${ }^{19}$ Por. M. KrąPIEC, Człowiek bytem osobowym. Św. Tomasza koncepcja człowieka, w: O godność osoby ludzkiej, Radom 2002, s. 35.

${ }^{20}$ Por. Leksykon ochrony praw człowieka..., s. 145-146.

${ }^{21}$ Por. M. KrąPIEC, Człowiek bytem osobowym..., s. 47.

${ }^{22}$ Por. J. Mazurek, Prawa człowieka w nauczaniu społecznym Kościoła, Lublin 1991, s. 78.
} 
filozofów: św. Tomasza z Akwinu, M. Schellera i I. Kanta ${ }^{23}$. Karol Wojtyła sformułował normę personalistyczną, która określa osobę ludzką, jako wartość samą w sobie, wartość tak cenną, że nie wolno jej nigdy używać, jako środka do celu, gdyż jest ona celem samym w sobie. Jedynym adekwatnym odniesieniem do niej jest postawa afirmacji i miłości ${ }^{24}$. Papież $w$ wielu swoich dokumentach podejmował temat godności osoby ludzkiej w aspekcie nadprzyrodzonym. Odniósł się do niej już w swojej pierwszej encyklice Redemptor hominis (1979 r.), w której powiedział, że człowiek tylko w Bogu może uzyskać pełną świadomość swojej godności, swojego wyniesienia, transcendentnej wartości samego człowieczeństwa, sensu swojego bytowania ${ }^{25}$. Człowiek nie jest w stanie poznać siebie w całej pełni bez odniesienia się do Chrystusa. Przez wcielenie Chrystus zjednoczył się jakoś z każdym człowiekiem, a przez odkupienie został on stworzony jakby na nowo. W ten sposób wcielenie i odkupienie podnoszą jeszcze bardziej ludzką godność. Dzieło odkupienia dokonane przez Chrystusa objawia pełnię ludzkiej godności, gdyż sprawia, że człowiek umiera dla grzechu, by mieć udział w życiu samego Boga. Człowiek, który chce zrozumieć siebie do końca, nie wedle jakichś tylko doraźnych, częściowych, czasem powierzchownych, a nawet pozornych kryteriów i miar swojej własnej istoty, musi ze swoim niepokojem, niepewnością, a także słabością, ze swoim życiem i śmiercią przybliżyć się do Chrystusa ${ }^{26}$. Godność człowieka jest nadprzyrodzona. Wynika z faktu, że człowiek jest osobą ludzką. Nie decyduje o tym niczyja wola, ani status człowieka, ale sam fakt bycia człowiekiem ${ }^{27}$.

\footnotetext{
${ }^{23}$ Por. R. Czekalski, Godność osoby ludzkiej. Nauczanie Jana Pawła II, Warszawa 2007, s. 16.

${ }^{24}$ Por. M. Marcinek, Godność osoby ludzkiej, w: Encyklopedia Nauczania Moralnego, red. J. Nagórny, K. Jeżyna, Radom 2005, s. 220.

${ }^{25}$ Por. Jan PaweŁ II, Encyklika Redemptor hominis, nr 11, w: Encykliki Ojca Świętego Jana Pawła II, Kraków 2005, s. 27.

${ }^{26}$ Por. Tamże, nr 10.

${ }^{27}$ Por. T. Borutka, Jan Paweł II jako obrońca godności i praw osoby ludzkiej, Polonia Sacra, nr 13, s. 99.
} 
Z kolei w adhortacji apostolskiej Ecclesia in Europa (2003 r.) Jan Paweł II przedstawił współczesne zagrożenia dla godności ludzkiej. Podkreślił, że współczesna cywilizacja charakteryzuje się sprzecznością z Ewangelią i godnością ludzką oraz rozwijającą się kulturą śmierci. Wynika to z rozpowszechnionego agnostycyzmu religijnego oraz pogłębiającego się relatywizmu moralnego i prawnego, który jest następstwem zagubienia prawdy o człowieku, jako niezbywalnym fundamencie podstawowych praw każdego ${ }^{28}$. Wśród zagrożeń dla godności ludzkiej papież wymienia m.in. zbyt niskie poszanowanie godności kobiet we współczesnych społeczeństwach oraz brak poszanowania godności człowieka ze strony środków masowego przekazu. Wyjściem $z$ tej sytuacji jest powrót do poszanowania godności człowieka. Stąd też papież mocno podkreślił jej znaczenie, że z różnorodnych duchowych korzeni wyrasta uznanie wartości osoby i jej niezbywalnej godności, świętości ludzkiego życia, znaczenia oświaty i wolności myśli, słowa, religii, jak też ochrona prawna jednostek i grup. Z tych korzeni zrodziło się dążenie do podporządkowania władzy politycznej prawu i poszanowaniu praw osoby i narodów ${ }^{29}$. Zadaniem Kościoła jest więc głoszenie nauki o Chrystusie, pośredniku między Bogiem a ludźmi, które jest drogą do pełni człowieczeństwa. Ponadto człowiek, który ma świadomość, jaką wartość posiada w oczach Boga, ma za zadanie postępować w sposób odpowiadający jego godności ${ }^{30}$.

\footnotetext{
${ }^{28}$ Por. Jan PaWe€ II, Posynodalna adhortacja apostolska Ecclesia in Europa Ojca Świętego Jana Pawła II, nr 9, Wrocław 2003.

${ }^{29}$ Por. Tamże, nr 19.

${ }^{30}$ Por. R. Hajduk, Współczesne zagrożenia godności ludzkiej według adhortacji apostolskiej Jana Pawła II Ecclesia in Europa, w: Godność człowieka i rodziny, red. W. Nowak, M. Tunkiewicz, Olsztyn 2007, s. 14.
} 


\section{Godność ludzka w dokumentach prawa świeckiego}

\subsection{W dokumentach prawa międzynarodowego}

Pierwszym powojennym aktem prawnym nawiązującym do godności człowieka była Karta Narodów Zjednoczonych z 26 czerwca 1945 r. W jej preambule znalazła się deklaracja o przywróceniu wiary w podstawowe prawa człowieka, w godność i wartość człowieka. Skorzystano z tego sformułowania, ponieważ twórcy dokumentu nie chcieli nawiązywać do jakiejkolwiek doktryny filozoficznej czy religijnej. Od tamtej pory pojęcie godności człowieka pojawiało się w zdecydowanej większości dokumentów dotyczących ochrony praw człowieka ${ }^{31}$.

W trzy lata później problem godności człowieka znalazł ważne miejsce w Powszechnej Deklaracji Praw Człowieka z 10 grudnia 1948 r. Świadczy o tym początek dokumentu, gdzie stwierdzono, że uznanie przyrodzonej godności oraz równych i niezbywalnych praw wszystkich członków wspólnoty ludzkiej jest podstawą wolności, sprawiedliwości i pokoju na świecie. Podkreślono też, że każdemu człowiekowi od urodzenia przysługuje godność ludzka oraz że wszyscy ludzie rodzą się wolni i równi w swej godności i w swoich prawach. Powszechna Deklaracja Praw Człowieka nie była umową międzynarodową, ale rezolucją uchwaloną przez Zgromadzenie Ogólne Narodów Zjednoczonych. Jednak wywarła wielki wpływ na powstający wówczas nowoczesny system ochrony praw człowieka.

Kolejnymi dokumentami, które traktowały o godności człowieka była Międzynarodowa Konwencja w sprawie likwidacji wszelkich form dyskryminacji rasowej z 7 marca 1966 r. ratyfikowana przez Polskę w 1969 r. ${ }^{32}$, a następnie Międzynarodowe Pakty Praw Człowieka z 16 grudnia 1966 r., na które składają się Międzynarodowy Pakt Praw Obywatelskich i Politycznych oraz Międzynarodowy Pakt Praw Gospodarczych, Społecznych i Kulturalnych, ratyfikowane przez

\footnotetext{
${ }^{31}$ Por. Leksykon ochrony praw człowieka..., s. 146-147.

${ }^{32}$ Por. Dz. U. nr 25, poz. 187.
} 
Polskę w 1977 r. ${ }^{33} \mathrm{~W}$ pierwszym z cytowanych paktów podkreślono, że każda osoba pozbawiona wolności, a więc więźniowie także posiadają również godność (art. 10 ust. 1), w drugim zaś, że nauczanie powinno zmierzać do pełnego rozwoju osobistego i poczucia godności ludzkiej oraz umacniać poszanowanie praw człowieka i podstawowych wolności (art. 13 ust. 1).

Do godności ludzkiej nawiązywały również takie dokumenty jak Międzynarodowa Konwencja o zwalczaniu i kierowaniu zbrodni apartheidu z 1973 r. $^{34}$, Międzynarodowa Konwencja przeciw apartheidowi w sporcie z $1985 \mathrm{r}^{35}$ czy Konwencja w sprawie zakazu tortur oraz innego okrutnego, nieludzkiego lub poniżającego traktowania albo karania $1984 \mathrm{r}^{36}$

Dużo uwagi sprawie godności ludzkiej poświęca Konwencja Praw Dziecka przyjęta przez Zgromadzenie Ogólne Narodów Zjednoczonych 20 listopada 1989 r. ${ }^{37}$ Dokument ten w kilku artykułach wyraźnie odwołuje się do godności człowieka mówiąc o dzieciach niepełnosprawnych (art. 23), o stosowaniu dyscypliny szkolnej (art. 28) o dzieciach oskarżonych z powodu złamania prawa (art. 40), o dzieciach chorych i pokrzywdzonych (art. 39).

4.2. W dokumentach prawa europejskiego

Godność człowieka znalazła swoje odzwierciedlenie również w europejskim porządku prawnym. Odniesienia do godności ludzkiej można znaleźć w prawie wydawanym przez Unię Europejską i Radę Europy. Wydają one normy prawne na podstawie decyzji państw je tworzących. Do najważniejszych dokumentów należy Konwencja o Ochronie Praw Człowieka i Podstawowych Wolności z 1950 r. i uchwalone później protokoły i Europejska Karta Społeczna z 1961 r., zrewidowana w 1996 r. Odwołanie do zasady godności człowieka

\footnotetext{
${ }^{33}$ Por. Dz. U. nr 38, poz. 167.

${ }^{34}$ Por. Dz. U. nr 32, poz. 186.

${ }^{35}$ Por. Dz. U. nr 14, poz. 100.

${ }^{36}$ Por. Dz. U. nr 63, poz. 378.

${ }^{37}$ Por. Dz. U. nr 120, poz. 526 z późn. zm.
} 
znalazło się również w Akcie Końcowym Konferencji Bezpieczeństwa i Współpracy w Europie (KBWE) z 1 sierpnia 1975 r., w którym państwa w zasadzie siódmej cytowanego dokumentu zobowiązały się do popierania i zachęcania z korzystania praw i wolności człowieka, które pochodzą z przyrodzonej godności ludzkiej osoby i mają podstawowe znaczenie dla jej swobodnego i pełnego rozwoju ${ }^{38}$. Było to bardzo mocne podkreślenie godności ludzkiej, jako źródła praw i wolności człowieka.

\subsection{W Konkordacie polskim}

Pojęcie godności ludzkiej zostało również użyte w Konkordacie, który został podpisany między Rzeczpospolitą Polską a Stolicą Apostolską dnia 28 lipca 1993 r i ratyfikowany 23 lutego 1998 r. $^{39}$, gdzie czytamy: „uznając, że fundamentem rozwoju wolnego i demokratycznego społeczeństwa jest poszanowanie godności osoby ludzkiej i jej praw" ${ }^{\prime 0}$. Na tej podstawie Konkordat przypomina podstawowe prawa i wolności człowieka wynikające z godności ludzkiej, w tym prawo do wolności sumienia i religii, bowiem celem podpisania tej dwustronnej umowy międzynarodowej było uregulowanie prawne sytuacji Kościoła katolickiego i wyznawców religii katolickiej w Polsce.

\subsection{W Konstytucji Rzeczypospolitej Polskiej}

W konstytucjach współczesnych państw godność ludzka występuje bardzo często, w tym także w polskiej ustawie zasadniczej. Należy jednak zaznaczyć, że ani Konstytucja RP z 2 kwietnia 1997 r. ${ }^{41}$, ani orzecznictwo sądowe, ani też nauka prawa nie zdefiniowały pojęcia godności. Stąd też trudniej z godności uczynić samoistny przedmiot ochrony prawnej. Sądy i Trybunał Konstytucyjny orzekając w różnych kwestiach odwołują się do pojęcia godności przy rozpatrywaniu

\footnotetext{
${ }^{38}$ Por. E. OMańczyк, Encyklopedia ONZ i stosunków międzynarodowych, Warszawa 1982, s. 20.

${ }^{39}$ Por. Dz. U. nr 51, poz. 318.

${ }^{40}$ Por. Konkordat, Preambuła.

${ }^{41}$ Por. Dz. U. nr 78, poz. 483.
} 
spraw dotyczących innych praw gwarantowanych konstytucyjnie lub ustawowo i przez ich pryzmat oceniają, czy nastąpiło naruszenie godności ${ }^{42}$.

Zgodnie z postanowieniem Konstytucji gwarancje wolności sumienia i religii podobnie jak innych praw i wolności człowieka mają swoje źródło w prawie naturalnym. Głównym źródłem praw i wolności sumienia i religii jest przyrodzona godność osoby ludzkiej. Art. 30 stanowi: „Przyrodzona i niezbywalna godność człowieka stanowi źródło wolności i praw człowieka i obywatela. Jest ona nienaruszalna, a jej poszanowanie jest obowiązkiem władz publicznych" ${ }^{\text {43 }}$. Cytowany artykuł powstał na podstawie prawno-naturalistycznej koncepcji definiowania godności człowieka ${ }^{44}$. Jest on niezwykle ważny, bowiem dzięki niemu Konstytucja będąc aktem prawa pozytywnego otwiera się na prawo naturalne oraz ustanawia zasadnicze wartości, na których opiera się jej wykładnia i stosowanie. Cytowany artykuł decyduje również o systemie praw i wolności poszczególnych osób ${ }^{45}$. Prawodawca ponadto w Konstytucji wyraźnie traktuje o godności człowieka, kiedy stanowi, że ustawa określająca zakres ograniczeń wolności i praw człowieka i obywatela w czasie stanu wojennego i wyjątkowego nie może ograniczać wolności i praw określonych w art. 30 (godność człowieka)..., art. 53 (sumienie i religia) ${ }^{46}$.

Według prawodawcy polskiego godność ludzka jest przyrodzona, niezbywalna, nienaruszalna i stanowi źródło wolności praw człowieka, a jej poszanowanie i ochrona należy do obowiązków władz publicznych. Godność ludzka jest przyrodzona, co oznacza, że posiada

${ }^{42}$ Por. B. Banaszak, Konstytucja Rzeczypospolitej Polskiej. Komentarz, Warszawa 2009, s. 170.

${ }^{43}$ Konstytucja RP, art. 30. Szerzej na ten temat por. J. KRUKowsKi, Konstytucyjna ochrona wolności sumienia i religii, w: Sześć lat Konstytucji RP. Doświadczenia i inspiracje, red. L. Garlicki, A. Szmyt, Warszawa 2003, s. 160.

${ }^{44}$ Por. Wolności i prawa człowieka w Konstytucji..., s. 30.

${ }^{45}$ Por. L. Garlicki, Komentarz do art. 30, w: Podstawowe problemy stosowania Konstytucji Rzeczpospolitej Polskiej. Raport końcowy z badań, red. K. Działocha, Warszawa 2006, s. 47.

${ }^{46}$ Por. Konstytucja RP, art. 233 ust. 1. 
ją każdy człowiek już od momentu stania się istotą ludzką. Prawodawca nie rozstrzyga jednak dokładnie tego momentu ${ }^{47}$. Niezbywalność polega na tym, że człowiek nie może zrzec się swojej godności. Nienaruszalność oznacza, że nikt, nawet władze publiczne czy organy państwowe, nie mogą pozbawić człowieka jego godności, ani jej ograniczać $^{48}$. Wręcz przeciwnie organy władzy publicznej mają obowiązek nie tylko szanować godność ludzką, ale również ją chronić. Muszą reagować we wszystkich sytuacjach, kiedy godność jest naruszana lub ograniczana. Jeżeli odpowiednie organy nie reagują $w$ takich przypadkach może interweniować np. Rzecznik Praw Obywatelskich, albo poszkodowany może w takim przypadku zaskarżyć państwo do Trybunału Praw Człowieka w Strasburgu ${ }^{49}$. Bardzo istotnym sposobem ochrony godności ludzkiej jest jej obrona za pomocą skargi konstytucyjnej złożonej do Trybunału Konstytucyjnego ${ }^{50}$.

Należy zauważyć, że zasada godności ludzkiej jest nie tylko podstawową regulacją systemu przepisów praw i wolności człowieka, ale jest przede wszystkim, jedną z podstawowych zasad ustroju Rzeczypospolitej ${ }^{51}$.

Ponadto należy też zaznaczyć, że Konstytucja RP nie jest jedynym aktem prawnym w Polsce zawierającym normy prawne dotyczące godności człowieka. Przepisy w tym względzie zawarte są także w wielu innych ustawach, rozporządzeniach i uchwałach.

\section{Zakończenie}

W podsumowaniu należy podkreślić, że gwarancje wolności sumienia i religii otrzymały ochronę prawną, w aktach prawa międzynarodowego i w konstytucjach poszczególnych państw, jako pierwsze z podstawowych praw człowieka. Podstawą tych gwarancji

\footnotetext{
${ }^{47}$ Por. Wolności i prawa człowieka w Konstytucji..., s. 37.

${ }^{48}$ Por. W. SkrzydŁo, Konstytucja Rzeczypospolitej Polskiej, Warszawa 2007, s. 34

${ }^{49}$ Por. Wolności i prawa człowieka w Konstytucji..., s. 38.

${ }^{50}$ Por. Konstytucja RP, art. 79 ust. 1.

${ }^{51}$ Por. L. Garlicki, Polskie prawo konstytucyjne. Zarys wykładu, Warszawa 2004, s. 82 .
} 
jest przyrodzona godność ludzka. W Polsce wolność religijna w zakresie podmiotowym i przedmiotowym jest regulowana przede wszystkim w Konstytucji $\mathrm{RP}^{52}$, która jest najwyższym aktem prawnym. Z jej postanowień wynika, że umowy międzynarodowe ratyfikowane przez Polskę, ustawy oraz inne akty prawne muszą być zgodne $\mathrm{z}$ konstytucyjną zasadą ochrony wolności sumienia i religii. Konstytucyjna ochrona wolności sumienia i religii wiąże nie tylko organy państwa, ale wszystkich obywateli, a także kościoły i związki wyznaniowe. Należy dodać, że w tej sprawie przepisy Konstytucji RP i Kościoła katolickiego są zgodne. Sfera sumienia i religii jest obszarem przeżyć wewnętrznych człowieka i dotyczy jego osobistych poglądów i jego wolności. Zarówno państwo jak i Kościół nie mogą ograniczać tej wolności, ponieważ ona nie pochodzi od tych instytucji. Źródłem wolności sumienia i religii jest przyrodzona i niezbywalna godność człowieka.

\section{Human dignity the basis of the right to religious freedom}

In his paper the author reflects on human dignity in the context of the right to religious freedom. First, he analyses the concept of fundamental human rights reaching back to ancient times, and then he discusses the concept of human dignity. He presents the concept of dignity in the teaching of the Catholic Church and in documents of secular law, among others, in the documents of international law, European law, the Polish Concordat, and the Polish Constitution. The author argues that inherent human dignity is the basis to guarantee freedom of conscience and religion. For that reason neither the State nor the churches, including the Catholic Church, can restrict this freedom, because it does not come from them.

SŁOWA KLUCzOWE: godność ludzka, wolność religijna, prawo kościelne, prawo świeckie, dokumenty

KEY WORDs: human dignity, religious freedom, Church law, secular law, documents

${ }^{52}$ Por. Konstytucja RP, art. 53. 


\section{Nota o Autorze:}

KS. DR hab. Józef ZdZisŁaW Wroceński SCJ, PRof. UKSW - doktor habilitowany nauk prawnych w zakresie prawa kanonicznego. W latach 19992005 prodziekan, a w latach 2005-2012 dziekan Wydziału Prawa Kanonicznego UKSW; kierownik Katedry Ustroju Kościoła i Kanonicznych Form Życia Konsekrowanego. Członek Consociatio Internationalis Iuris Canonici Promovendo (Rzym), Towarzystwa Naukowego Katolickiego Uniwersytetu Lubelskiego Jana Pawła II oraz Stowarzyszenia Kanonistów Polskich. Redaktor Naczelny wydziałowego kwartalnika „Prawo Kanoniczne”, Zastępca Redaktora Naczelnego czasopisma „Kościół i Prawo” oraz członek kilkunastu Redakcji i Rad Naukowych czasopism. 